\title{
Pasmodium Vivax Malaria Complicated by Neurological, Jaundice and Haemophagocytic Syndrome
}

\author{
Ram Kumar TV', Baghmar $\mathbf{S}^{2}$ \\ ${ }^{1}$ Dr. T.V. Ram Kumar, MBBS, MD. (Paediatrics), Senior Resident, ${ }^{2}$ Dr. Shilpa Baghmar, MBBS, MD (Paediatrics), \\ Senior Resident. Both from Maulana Azad Medical College, New Delhi, India.
}

Address for Correspondence: Dr. TV Ram Kumar, E-mail: starringram@gmail.com

\begin{abstract}
We are describing a case of plasmodium vivax malaria in a child with complications including pancytopenia secondary to marrow involvement, jaundice and neurological features. The child improved with antimalarial treatment.
\end{abstract}

\section{Introduction}

$\mathrm{H}_{\mathrm{a}}^{\mathrm{e}}$ emophagocytic syndrome (HS) is a disease of mononuclear phagocytic system, which is characterised by benign, generalized histiocytic proliferation, with hemophagocytosis (phagocytosis of haematopoietic cells) observed in bone marrow ${ }^{1}$. This syndrome is commonly associated with haematological malignancies, autoimmune conditions, viral, bacterial or parasitic infections ${ }^{1,2}$. There are infrequent reports of plasmodium vivax presenting with neurological features in adults and few of them in children ${ }^{3,4,5,6,7}$. There are rare case reports of falciparum malaria presenting as $\mathrm{HS}^{7,8}$ and few with p. vivax in adults ${ }^{9,10}$. We are describing a case of plasmodium vivax infection in a $9 \mathrm{yr}$ female child complicated by hemophagocytosis, jaundice and neurological features that resolved by antimalarial treatment.

\section{Case Report}

A 9- year female child presented to out-patient department of Lok Nayak Hospital, Delhi, India with history of high grade fever associated with chills and rigors and generalised headache for seven days. The parents noticed petechiae over the arms, legs and abdomen for one day and altered sensorium for eight hours. There were 3-4 episodes of non-bilious or nonprojectile vomiting. This was not associated with any weight loss, frequent infections or bone pains. There was no history of contact with a case of tuberculosis. There was no history of seizures in this child. There was no history of any previous blood transfusions. Clinically, the child was in stupor. The vitals were maintained.

There was severe pallor, icterus and petechiae. This child had liver $5 \mathrm{~cm}$ below costal margin (span $8 \mathrm{~cm}$ ) and spleen $6 \mathrm{~cm}$ along long axis. There was terminal neck rigidity. On investigation, $\mathrm{Hb}: 4.8 \%$, TLC: $3200 / \mathrm{cu}$ $\mathrm{mm}$, DLC: $55 \%$ polymorphs, $40 \%$ lymphocytes, $5 \%$ of eosinophils (normal for this geographic region), platelet count: $30,000 / \mathrm{mm}^{3}$, peripheral smear was positive for ring forms and gametocytes of plasmodium vivax as shown in Fig 1.

Antigen test (OptiMAL) was positive for $p$. vivax and negative for $p$. falciparum. Blood cultures were sterile and widal titres were $<1: 40$. CSF was acellular with normal biochemistry and LATEX test negative for meningococcus. Dengue serology was negative. Liver function tests: Total Bilirubin $=3.8 \mathrm{mg} / \mathrm{dl}, \mathrm{ALT}=234 \mathrm{IU} / \mathrm{L}$, $A S T=428 \mathrm{IU} / \mathrm{L}$ and $\mathrm{ALP}=580 \mathrm{IU} / \mathrm{L}$. The serum was negative for anti $\mathrm{HAV}, \mathrm{HBsAg}$, anti $\mathrm{HBc}$, anti $\mathrm{HCV}$ and anti HIV. Serum LDH was 890 IU/L (reference: 115-250 IU/L), ferritin level = $897 \mathrm{ng} / \mathrm{ml}$ (reference 15-332 $\mathrm{ng} / \mathrm{ml}$ ) and fasting triglyceride levels $=387 \mathrm{mg} / \mathrm{dl}$ (reference: $30-160$ $\mathrm{mg} / \mathrm{dl}$ ). Prothrombin time was normal. The patient could not afford for fibrinogen levels and D-dimer assay. Bone marrow study was done and it showed hypercellular marrow, $M: E=1: 2$ with normoblastic reaction. Histiocytes were increased in marrow with hemophagocytosis and brown pigment of $p$ vivax as shown in Fig 2.

She did not have G6PD deficiency. The child was treated with standard dosage of chloroquine, fluids, ranitidine and metoclopramide. The sensorium improved 
in 8 hours and child accepted diet by 12 hours. The counts repeated after 3 days showed an improvement with $\mathrm{Hb}$ : 8.3\%, TLC: $6750 / \mathrm{mm}$, platelet count: 1.4 lakhs/cu mm. Repeat smears were negative for $p$. vivax. Serum ferritin and LDH levels normalised during follow up. The child was discharged in a hemodynamically stable state with 14 days of primaquine.

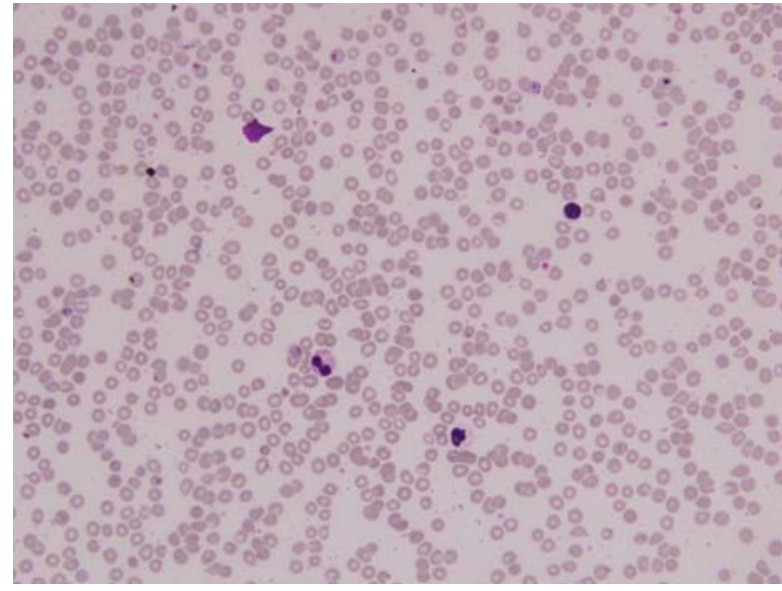

Fig 1: Showing ring forms of $p$. vivax in the peripheral smear of the patient.

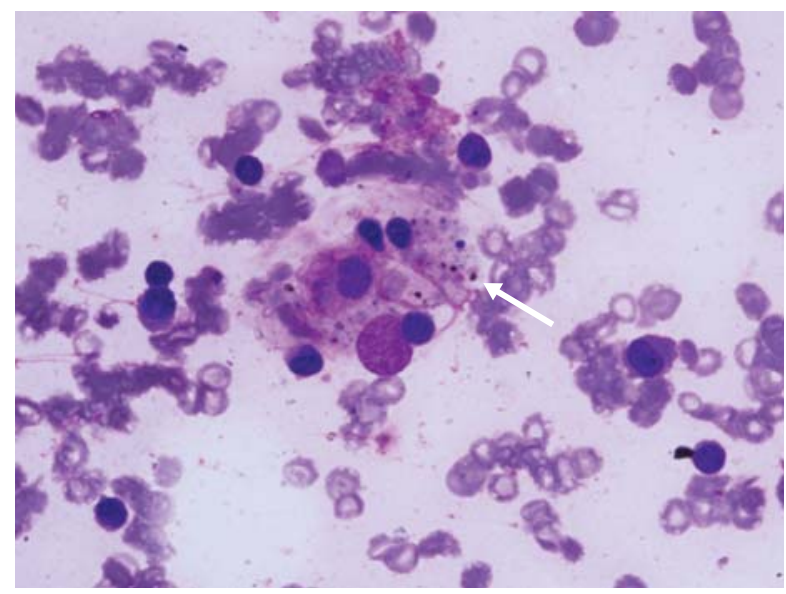

Fig 2: Bone marrow smear of patient showing hemophagocytosis and malarial pigment (arrow).

\section{Discussion}

There has been increasing reports of $p$. vivax in children during last few years causing several complications. There are 2 recent cases of $p$. vivax impicated in cerebral malaria ${ }^{3}$. Any patient infected with p. vivax exhibiting severe malaria should be presumed to be suffering from mixed infection ${ }^{3,4}$. However, there are increasing reports vivax can present with both sequestration and non-sequestration related complications, which were commonly associated with $p$. falciparum infection ${ }^{6}$.

The patient in our case in addition to neurological features had pancytopenia as a result of hemophagocytosis (marrow picture). In the marrow, there were increased histiocytes and phagocytosis of R.B.C., leukocytes and platelets. There is presence of malarial pigment in the cytoplasm. There was clinical jaundice with derranged liver functions. The mechanism of HS is not known, but high serum levels of cytokines (IL $-18,1 \alpha$, TNF- $\alpha$ ) have been reported in various studies. This has been studied in animal models and humans, that there is hyperactivity of $\mathrm{TH} 1$-cells and their mediated production of aforesaid cytokines ${ }^{11,12,13,14}$. The levels of high TNF- $\alpha$ have been seen in cerebral malaria progressing to coma and death ${ }^{15}$. HS is one of the causes of pancytopenia in these infections. Bone marrow examination is not usually under-taken for the purpose of a diagnosis of malarial infection that may result in under diagnosis.

In various literatures, HS has been treated with prednisolone or plasma exchange $7,8,16,17,18,19$. However, in our case, there was good clinical and haematological improvement with chloroquine alone. We recommend a marrow examination in malarial cases with severe or persistent decrease in haemoglobin or pancytopenia.

\section{References}

1. Imashuku S. Differential diagnosis of hemophagocytic syndrome: underlying disorders and selection of the most effective treatment. Int $J$ Hematol 1997;66:135-151.

2. Fisman DN. Hemophagocytic syndromes and infection. Emerg Infect Dis 2000;6:601-608.

3. Ozen M, Gungor S, Atambay M, Daldal N. Cerebral malaria owing to Plasmodium vivax: case report. Ann J Pediatr 2006;26:141-144.

4. White NJ. Malaria. In: Cook GC, Zumla Al, eds. Manson's Tropical Diseases. 21st edn. London: Elsevier Saunders; 2002;1205-1278.

5. Sachdev $\mathrm{H}$, Mohan M. Vivax cerebral malaria. $J$ Trop Pediatr 1985;31:213-215.

6. Kochar D, Saxena V, Singh N, Kochar S, Kumar $\mathrm{S}$, Das A. Plasmodium vivax malaria. Emerg Infect Dis 2005;11:132-134.

7. Thapa R, Patra V, Kundu R. plasmodium vivax cerebral malaria. Indian Pediatr 2007;433-434.

8. Sermet-Gaudelus I, Abadie V, Stambouli F, Hennequin C, Lenoir G, Gendrel D. Haemophagocytic syndrome in plasmodium falciparum malaria. Acta Pediatr 2000;89:368-369. 
9. Ohnishi K, Mitsui K, Komiya N, Iwasaki N, Akashi A, Hamabe Y. Clinical case report: Falciparum malaria with hemophagocytosis syndrome. Am J Trop Med Hyg 2007;76(6):1016-1018.

10. Aouba A, Noguera M, Clauvel J, Quint L. Haemophagocytic syndrome associated with plasmodium vivax. Br J Haematol 2000;108:832833.

11. Kwiatkowski D, Hill A, Sambou I, Twumasi P, Castracane J, Manogue et al. TNF concentration in fatal cerebral, non-fatal cerebral and uncomplicated Plasmodium falciparum malaria. Lancet 1990;336:1201-4.

12. Morris Jones MR, Goodier R, Langhorne J. The response of $ү \delta T c e l l s$ to Plasmodium falciparum is dependent on activated CD4 T cells and the recognition of $\mathrm{MHC}$ class I molecules. Immunology 1996;89:405-12.

13. Clark LA, Chaudhri G. Tumor necrosis factor may contribute to the anemia of malaria by causing dyserythropoiesis and erythrophagocytosis. $\mathrm{Br} J$ Haematol 1988;70:99-103.

14. Takada $H$, Ohga $S$, Mizuno $Y$, Suminoe $A$, Matsuzaki $A$, Ihara $K$ et al. Oversecretion of IL18 in haemophagocytic lymphohistiocytosis: A novel marker of disease activity. $\mathrm{Br} J$ Haematol 1999;106:182-189.
15. Grau G, Taylor T, Molyneux M, Wirima J, Vassalli P, Hommel M, et al. Tumor necrosis factor and disease severity in children with falciparum malaria. $\mathrm{N}$ Engl J Med 1989;320:1586-91.

16. Koizumi K, Yokoyama K, Nishio M, Shibata S, Ozutumi K, Yamaguchi M et al. A case with virusassociated hemophagocytic syndrome (VAHS) complicated by rhabdomyolysis which were associated with herpes-simplex virus infection. Jpn J Clin Hematol 1996;37:40-45.

17. Fujiki R, Shiraishi K, Noda K, Ohshita Y, Fukahori $\mathrm{S}$, Johjima $\mathrm{H}$ et al. A case of hemophagocytic syndrome associated with military tuberculosis. Kekkaku 2003;78(6):443-448.

18. Goto S, Aoike I, Shibasaki Y, Morita T, Miyazaki $\mathrm{S}$, Shimizu $\mathrm{T}$ et al. A successfully treated case of disseminated tuberculosis-associated hemophagocytic syndrome and multiple organ dysfunction syndrome. Am J Kid Dis 2001;38:E19.

19. Sanada S, Ookawara S, Shindo T, Morino K, Ishikawa $\mathrm{H}$, Suzuki M. A case report of the effect of plasma exchange on reactive hemophagocytic syndrome associated with Toxic shock syndrome. Therap Aphre Dialy 2004;8:503-506.

\section{How to cite this article?}

Ram Kumar TV, Baghmar S. Pasmodium Vivax Malaria Complicated by Neurological, Jaundice and Haemophagocytic Syndrome. J Nep Paedtr Soc 2010;30(3):168-170. 